\title{
Perception of Forensic Accounting Education as a Tool for Anti- Fraud in Libya
}

\author{
Ali Altuğ Biçer ${ }^{1}$, Mohamed Issa ${ }^{2 *}$ \\ ${ }^{1}$ İstanbul Commerce University \\ ${ }^{2}$ University of Benghazi
}

*Corresponding Author: Mohamed Issa, University of Benghazi

\begin{abstract}
The harm of financial fraud and other financial disputes have raised the awareness of forensic accounting which can provide significant aid in preventing, investigating and resolving these issues. Forensic accountants provide these services with knowledge of legal requirements. The purpose of this study was to collect information about the opinions of accounting academicians on the perception and the need of forensic accounting education at universities in Libya, also their willingness to implement it to detect and deter fraud. Using combined data set consisted of information on forensic accounting benefits and education for a random sample of academicians in Libyan universities. The study resulted that there was high demand for and high interest in forensic accounting education and practice in Libya, also they were willing for the proposed forensic accounting topics to be incorporate into accounting curriculum in Libya.
\end{abstract}

Keywords: Forensic Accounting, Accounting Education and Fraud.

\section{INTRODUCTION}

Fraud is an intent act. Fraud is a global phenomenon that has increased every day (Abdou, Delamaire, Pointon, 2009). Fraud is spread in both developed and developing countries.

Forensic accounting is process of collecting and analyzing of data to reconstruct, detect, or support a claim of financial fraud. However, forensic accounting includes of litigation support and investigative accounting techniques. Litigation support provides assistance of all nature in existing or pending litigation. It deals primarily with issues related with the quantification of economic damages, while investigative accounting is associated to the investigation of criminal matters. The main steps in forensic analytics are data collection, data preparation, data analysis and reporting, therefore, investigating corporate fraud cases is one of the highest priorities of forensic accountants (Nigrini, 2011).

Public is wary of fraud that led to use forensic accounting to stop this issue which destroys many countries. Therefore, the forensic accounting becomes more important to control the practices, and responsibilities. In addition, it looks for the wrong doings and to make strict control on that place to prevent happening of such events.

Therefore, that highlights the need to incorporate forensic accounting education in the accounting curriculum at university level. Much research has shown that there are universities that started offering forensic accounting courses while others have introduced full academic programs in the area (Smith and Crumbley, 2009). Because, the awareness of forensic accounting helps to fight corruption. Libya has not taken any particular action to introduce and popularize forensic accounting. Then, it would be testified the perception of the forensic accounting and its expected role for anti-fraud.

\subsection{Forensic Accounting}

Forensic accounting can be defined as the science of gathering and presenting financial information in a form that will be accepted by a court of jurisprudence against perpetrators of economic crimes (Renzhou, 2011). 
Many economists, analysts and experts have argued the importance and extent of the influence of the concept of forensic accounting in many aspects of economic, legal and social efforts to the benefit of individuals, institutions and societies as a whole in the developed and developing countries alike.

The Association of Certified Fraud Examiners (ACFE) (2012) refers to this definition of forensic accounting as "fraud examination". Yet, the terms of the fraud examination (fraud auditing) is a subset of forensic accounting.

\subsection{Forensic Accounting Services}

Forensic accounting has three major aspects (Akyel, 2012, 81-83):

- Litigation Support Consulting: It is described as professional or accounting support for case. To collect necessary documents to support or refute case. To revise the related documents to make examination of case and the statements. To report the strong and weak points.

- Fraud Examination (Investigative Accounting): A typical investigative accounting assignment would be an investigation of employee theft. The different types of complex fraud due to the technology and complicated business transactions, therefore it seems impossible for a non-expert to detect and prevent them. They can be solved by experts and have occupational knowledge on the subject.

- Expert Witness: An expert witness is a specialist who has special knowledge, skill, training or experience is qualified to provide testimony about matters that exceed the common knowledge of ordinary people.

\subsection{Forensic Accounting Education}

The education of a forensic accountant should cover all skills, knowledge and abilities needed to effectively discharge the expected duties. Forensic accounting is known as a practice that uses technology and techniques to investigate, assess and expose financial issues and fraudulent activities involved in the areas of accounting, finance, management, and other business areas where illegal financial acts or financial disputes might take place. Understanding the role and expectations of a forensic accountant is fundamental to the design of an appropriate educational program.

In 2008, DiGabriele said that forensic accountants should possess various combinations of skill and knowledge in accounting, auditing, law, and investigation techniques. If the one wants to be a profession in the field of forensic accounting then he/she should have knowledge and skills that are related to the field, after taking the basic principles and skills: Criminology; the legal, regulatory, and professional environment; and ethics. Fraud and forensic accounting, misappropriated asset, fraud and falsified financial statements.

Forensic services and other litigation services and advisory require knowledge, skills, training, and education to be done successfully.

There are academicians preferred to integrate forensic accounting topics in the existing accounting courses, whereas the certified fraud examiners preferred to be trained as a separate program. Some universities have been teaching forensic accounting as course of its regular accounting program and that made good result.

\subsection{Fraud}

Fraud is a significant threat that cause of damage the economy and financial stability of the country. Fraud is also recognized as "the acts in which the power of the higher position is used for personal gain in a manner that contravenes the rules of the law" (Nguyen and Dijk, 2012).

International Professional Practices Framework (IPPF) (2014) defines fraud as:

"Any illegal act characterized by deceit, concealment or violation of trust. These acts are not dependent upon the threat of violence or physical force. Frauds are perpetrated by parties and organizations to obtain money, property or services; to avoid payment or loss of services; or to secure personal or business advantage"

Nowadays, the worst issue in the business is fraud that made many firms started restrict systems in way to stop this issue. Smith and Crumbley (2009) stated that fraud occurs when a person has accessible data sets. The data collected through logs and user behavior, can be a great advantage for fraud detection in order to learn from the recent schemes. 
Fraud has strong effects socially, politically and economically in all countries. Fraud undermines financial situation for the firms and countries, also it slows down the development and improvement on them. Fraud attacks the financial foundation of firms and countries by destroying the real situation of the firms, perverting the rule of law and creating fraudulent information. Economic development is stunted by the fraud because of discouraging the businesses within the country to overcome the startup costs.

Due to the increase and integration in business, fraud become very complex and even more difficult to detect, therefore, there are many organizations and individuals have asked for professional to deal with such issue.

\subsection{Practical Studies}

Brooks and Labelle (2006) had offered and designed forensic accounting programs. Also, they provided some exploratory evidence on the type of services currently rendered by investigative and forensic accountants in Canada.

In 2011, Islam, Rahman and Hossan made a study about using forensic accounting as tool for detecting fraud and corruption in Bangladesh. The sample size of this study was 100. This study examined the application of forensic accounting in Bangladesh and recommended steps that should be taken for improving the utilization of forensic accounting as an effective tool for anti-fraud and corruption in Bangladesh.

Daniels, Ellis and Gupta (2013) tested the perceptions regarding the relative importance of fraud and forensic topics to include in the accounting curriculum. The samples were CPAs who were registered in AICPA (the American Institute of Certified Accountants) and the mailing list of educators. Finally, this study can assist educators and administrators in the selection process of fraud related topics to include in the accounting curriculum.

Handley and Mohamed in 2014 made a study that examined the potential means available to company managers, auditors and regulators of preventing, detecting and reacting to financial statement fraud in Malaysia. Research was conducted by means of interviews with company managers, auditors and regulators. It was found that management integrity and the development of internal systems to prevent fraudulent reporting was very high. However, the probability of financial statement fraud is reduced by regulators. Regulations that were set to deter and react to cases where such frauds are detected helped to reduce the number of the cases.

Ramadhan (2015) studied the perceptions of certified accountants about the awareness, demand, benefits, relevance and contents of forensic accounting education in a developing country in Bahrain. The study concluded that all respondents are familiar with forensic accounting and they expect demand on forensic accounting to increase in the future.

\subsection{Research Rationales and Motivations}

The topic of forensic accounting has gotten attention for business people due to financial fraud which dominance the news in the past few decades. In addition, fraud is the most dangerous phenomenon which caused a lot of difficulties to many countries to fix their economy. Also, it opened a lot of discussions calling for establishment of strict forensic accounting mechanisms to eliminate this phenomenon.

Moreover, the attention has increased about the problem of fraud in the world especially after the recession in many regions and the pass for social effects of fraud in the world. The fraud has destroyed the wealth of many countries in the world.

Similarly fraud has increasingly become a major problem in Libya, according to Zakari and Menacere (2012) corporate businesses in Libya is rife with fraud and embezzlement. In addition, Libya was ranked 146th out of 170 countries on Transparency International's 2016 corruption perception index.

Despite the efforts for facing the fraud, the fraud rates has been steadily increasing due to the interaction of economic and social, political and administrative factors in Libya. Even though, the forensic accounting has not been taught in Libyan universities and practiced in the Libyan firms. Therefore, the main question of this research is, "What is the academicians' perception about teaching forensic accounting to constrain fraud?" 


\subsection{Importance Of The Research}

The main role of forensic accounting is to detect, deter and control fraud. Studying the forensic accounting will help to identify what various respondents perceive the importance of forensic accounting mechanisms and their acceptance to be implemented in Libya for antifraud. Therefore, it is expected that the research will contribute to the knowledge of several points regarding forensic accounting.

\section{RESEARCH METHODOLOGY AND SAMPLING}

To achieve the objectives of this study, the data was collected based on questionnaire and it was distributed randomly over academicians. It is assumed that academicians are more likely to be familiar with forensic accounting topic than other accounting professions in Libya. There are 11 universities were connected in Libya. The questionnaire consists of two parts:

Part one provides information about the perceived benefits future and the demand on forensic accounting.

Part two covers the relative important topics related to a forensic accounting course. A list of (26) topics relating to the forensic accounting services, were included in the questionnaire. The selection of topics was based on previous studies in different countries around the world about forensic accounting education such as Brooks and Labelle (2006); Rezaee, Ha and Lo (2014) and Daniels, Ellis and Gupta (2013). The proposed topics are measured on a five-point Likert scale rated from $1=$ strongly disagree to $5=$ strongly agree.

\subsection{Internal Consistency Reliability}

Cronbach alpha is one of the most popular reliability statistic test. It is a tool for assessing the internal consistency (average correlation) of items in a questionnaire. The higher the alpha, the more reliable the test is. Nunnally and Bernstein (1994) stated that 0.7 and above is acceptable. Thus, Cronbach alpha was used to evaluate the internal consistency reliability associated with scores derived from the scale. This study were distributed among three general categories of forensic accounting education (forensic accounting, fraud investigation and corporate governance). The results of testing the data show that for each of the three group and overall, it is more than the minimum required (0.7), and they are respectively $0.737,0.780$ and 0.932 . Also the overall average is 0.915 . Thus, it proves that internal consistency about the items is in high level.

\section{RESUltS AND ANALYSIS}

This section discusses the major findings and ties them with the research main questions. The following parts discuss and summarize the major findings of the study in order to determine the level of perception of the forensic accounting education in Libya and the acceptance to be taught for antifraud. The study adopted simple random sampling technique to draw the samples from the four groups of respondents as shown in the below table. The overall study sample size was 40 and they were the majority of academicians in Accounting in Libya.

The $32.5 \%$ of respondents were lecturers and $32.5 \%$ were professors. The researchers were $15 \%$ and the graduate students were $20 \% .60 \%$ of respondents were males and $40 \%$ were females.

The following table (3) shows the professional qualification for the respondents. $45 \%$ of the respondents were CPA; while the 5\% of them were CFA (They took the certification out of Libya). The rest of respondents had another professional qualification.

Table 1: Benefits of Forensic Accounting Education - Percentage Distribution of Responses and Descriptive Statistics

\begin{tabular}{|l|c|c|c|c|c|c|c|}
\hline \multicolumn{1}{|c|}{ Question } & $\begin{array}{c}\text { Strongly } \\
\text { Agree }\end{array}$ & Agree & Neutral & Disagree & $\begin{array}{l}\text { Strongly } \\
\text { Disagree }\end{array}$ & Mean & Std. \\
\cline { 2 - 7 } & $\mathbf{5}$ & $\mathbf{4}$ & $\mathbf{3}$ & $\mathbf{2}$ & $\mathbf{1}$ & \\
\cline { 1 - 6 } $\begin{array}{l}\text { a. Strengthen the credibility of financial } \\
\text { reporting }\end{array}$ & 20 & 42.5 & 30 & 7.5 & 0 & 3.75 & 0.87 \\
\cline { 1 - 6 } b. Promote responsible corporate & 35 & 60 & 5 & 0 & 0 & 4.3 & 0.564 \\
\hline
\end{tabular}




\begin{tabular}{|l|c|c|c|c|c|c|c|}
\hline governance & & & & & & & \\
\hline $\begin{array}{l}\text { c. } \text { Increase demand on forensic } \\
\text { accountants who possess forensic } \\
\text { accounting skills }\end{array}$ & 20 & 30 & 45 & 2.5 & 2.5 & 3.63 & 0.925 \\
\hline $\begin{array}{l}\text { d. } \text { Make students more desirable in the } \\
\text { marketplace }\end{array}$ & 20 & 55 & 15 & 10 & 0 & 3.85 & 0.864 \\
\hline $\begin{array}{l}\text { e. } \text { Satisfies society's demand for forensic } \\
\text { accounting }\end{array}$ & 27 & 45 & 17.5 & 7.5 & 2.5 & 3.88 & 0.992 \\
\hline $\begin{array}{l}\text { f. } \text { Prepare students to engage in fraud } \\
\text { examination }\end{array}$ & 15 & 47.5 & 25 & 0 & 12.5 & 3.53 & 1.154 \\
\hline $\begin{array}{l}\text { g. } \text { Prepare students to engage in litigation } \\
\text { support consulting }\end{array}$ & 32.5 & 50 & 17.5 & 0 & 0 & 4.15 & 0.7 \\
\hline $\begin{array}{l}\text { h. } \text { Prepare students to engage in expert } \\
\text { witnessing }\end{array}$ & 35 & 47.5 & 17.5 & 0 & 0 & 4.18 & 0.712 \\
\hline
\end{tabular}

As it shows in the table 1, the academicians were asked to evaluate their perceptions about the benefits of forensic accounting education and it shows that all of which were in the agree side because the means for all questions were above average (3) rating.

Moreover, the benefits of forensic accounting education averaged the most highest ones were: "Promote responsible corporate governance", "Prepare students to engage in expert witnessing" and "Prepare students to engage in litigation support consulting" (means respectively are 4.30, 4.18 and 4.15), which indicate that the respondents connect the forensic accounting with legal application of accounting in firms such as corporate governance and prepare students to engage in litigation support and expert witnessing. The standard deviation for all benefits is low indicating that there is no dispersion about benefits of forensic accounting education.

Table 2: Proposed Topics in a Forensic Accounting Course

\begin{tabular}{|c|c|c|c|c|}
\hline & Minimum & Maximum & Mean & Std. \\
\hline 1. Analytical review procedures & 2 & 5 & 3.69 & .731 \\
\hline 2. Bribery and corruption investigation & 3 & 5 & 4.10 & .672 \\
\hline 3. Careers in forensic accounting & 1 & 5 & 3.54 & .854 \\
\hline 4. Conducting internal investigations & 1 & 5 & 3.69 & .800 \\
\hline 5. Conflicts of interest investigating techniques & 3 & 5 & 3.90 & .552 \\
\hline 6. Financial statement fraud & 4 & 5 & 4.26 & .442 \\
\hline 7. Fraud detection and deterrence programs & 2 & 5 & 4.10 & .672 \\
\hline 8. Intellectual property fraud & 3 & 5 & 4.35 & .533 \\
\hline 9. Internal control evaluation & 3 & 5 & 4.20 & .516 \\
\hline 10. Interview skills and legal aspects of interview & 2 & 5 & 4.03 & .620 \\
\hline 11. Professional standards pertaining to forensic accounting & 3 & 5 & 4.15 & .427 \\
\hline 12. Security and privacy & 4 & 5 & 4.38 & .490 \\
\hline 13. Techniques in locating hidden assets & 4 & 5 & 4.50 & .506 \\
\hline 14. Business valuations & 3 & 5 & 4.38 & .586 \\
\hline 15. Compliance with applicable laws and regulations & 3 & 5 & 4.18 & .683 \\
\hline 16. Corporate governance & 3 & 5 & 4.31 & .521 \\
\hline 17. Earnings management & 3 & 5 & 4.38 & .544 \\
\hline 18. Effective report writing & 3 & 5 & 4.28 & .560 \\
\hline 19. Expert testimony and expert witness techniques & 3 & 5 & 4.41 & .549 \\
\hline 20. Knowledge of the legal system & 3 & 5 & 4.11 & 649 \\
\hline 21. Legal elements of fraud & 3 & 5 & 4.16 & .594 \\
\hline 22. Litigation consulting techniques & 3 & 5 & 4.15 & .432 \\
\hline 23. Principles of ethics & 2 & 5 & 3.93 & .694 \\
\hline 24. Resolution of allegations of misconduct & 2 & 5 & 4.07 & .572 \\
\hline 25. Rules of evidence & 3 & 5 & 3.95 & .605 \\
\hline 26. Shareholder litigation & 2 & 5 & 3.87 & .732 \\
\hline
\end{tabular}

As it shows in the table 2, there are 26 topics were selected for forensic accounting education and they indicate that respondents understood all topics related to forensic accounting education. Moreover, all 
the means of the topics were above the average 3 rating. It is interesting to know that all respondent gave the highest rank to the techniques in locating hidden assets, due to the bribery and corruption was the extremely highest frequent in Libya. Moreover, the standard deviations are low indicating that there is some consensus among the respondents regarding the importance of each topic in forensic accounting education.

\section{CONCLuSion}

This study confirmed that respondents' awareness was high about forensic accounting education as tool for anti-fraud. In addition, the study tested the expectation of the respondent about the future demand and benefits of forensic accounting education via proposed topics and it resulted that the respondents highly realized the important of forensic accounting in the business environment as tool to increase the confidence in the country.

They also realized that forensic accounting is valuable for accounting students because it helps in framing the future direction and role of forensic accounting education and application. The study also concluded that education influence the level of awareness in terms of recognizing the benefits of forensic accounting. Moreover, the study found that the majority of respondents believed that forensic accounting topics should be incorporated in accounting curriculum universities. The course of forensic accounting that is taught at the undergraduate level should contain all topics that were proposed in this study.

However, it may be there are two limitations to the study. First, this study includes only twenty six proposed topics to be taught to the students, which give them the necessary skills and knowledge to prevent and detect financial fraud. Thus, the 26 topics may not cover all topics related to forensic accounting. Second, the results of the study are based on the responses of questionnaire, which may be limited by the view and subjectivity of academicians who teach accounting.

\section{REFERENCES}

[1] Abdou, H., Delamaire, L., \& Pointon, J. (2009). Credit card fraud and detection techniques: a review. Business Perspectives. 4(2), 57-68.

[2] ACFE (Association of Certified Fraud Examiners). (2012). Report of Nations on Occupational Fraud and Abuse.

[3] Akyel, N. (2012). Forensic Accounting Training: A Proposal for Turkey. Social and Behavioral Sciences, $55,77-86$.

[4] Brooks, L. J. \& Labelle, R. (2006). CAP Forum on Forensic Accounting in the Post-Enron World: Education for Investigative and Forensic Accounting. Accounting Perspectives, 5(2), 287-306.

[5] Daniels, B., Ellis, Y., \& Gupta, R. D. (2013). Accounting Educators and Practitioners' Perspectives on Fraud and Forensic Topics in the Accounting Curriculum. Journal of Legal, Ethical and Regulatory Issues, 16(2), 93-106.

[6] DiGabriele, J. (2008). Implications of regulatory prescriptions and audit standards on the evaluation of forensic accounting in the audit process. Journal of Applied Accounting Research, 10(2), 109-121.

[7] Handley, M., \& Mohamed, N. (2014). Financial Statement Fraud Risk Mechanisms and Strategies: the case studies of Malaysian commercial companies. Social and Behavioral Sciences, 145, 321 - 329.

[8] IPPF (International Professional Practices Framework) (2014). Fraud Detection Using Data Analytics in the Banking Industry.

[9] Islam, J., Rahman, H., \& Hossan, T. (2011). Forensic Accounting as a Tool for Detecting Fraud and Corruption: An Empirical Study in Bangladesh. ASA University Review, 5(2).

[10] Nigrini, M. (2011). Forensic Analytics Methods and Techniques for Forensic Accounting Investigations. Wiley \& Sons, Inc.

[11] Nguyen \& Dijk (2012). Fraud, growth, and governance: Private vs. state-owned firms in Vietnam. Journal of Banking \& Finance, 36(11), 2935-2948.

[12] Nunnaly \& Bernstein (1994). Psychometric Theory. 3 edition. McGraw-Hili, Inc, United States of America.

[13] Ramadhan, S. (2015). Certified Accountants' Perceptions of Forensic Accounting Education: The Case of Bahrain. International Journal of Finance and Accounting, 4(2), 109-118.

[14] Rezaee, Z., Ha, M., \& Lo, D. (2014). China Needs Forensic Accounting Education. Open Journal of Social Sciences, 2, 59-65.

[15] Renzhou, D. (2011). Research on Legal Procedural Functions of Forensic Accounting. Energy Procedia, $5,2147-2151$. 
[16] Smith, G. \& Crumbey, D. (2009). How Divergent are Pedagogical View Toward the Fraud/Forensic Accounting Curriculum. Global Perspectives on Accounting Education, 6, 1-24.

[17] Zakari, M., \& Menacere, K. (2012). The challenges of the quality of audit evidence in Libya. African J. Accounting, Auditing and Finance, 1(1), 3-24.

\section{AUTHORS' BIOGRAPHY}

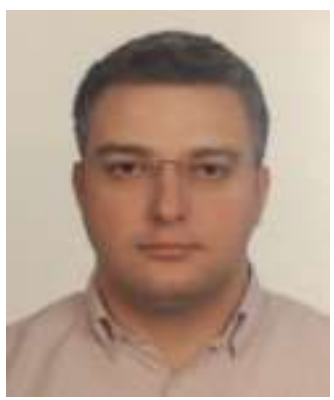

Ali Altuğ Biçer, Graduated from Marmara University Faculty of Economics and Administrative Sciences, department of Business Administration in 2004. He continued his studies in Marmara University and received his master degree in Accounting and Finance in 2006 and his $\mathrm{PhD}$ degree in the same field in 2012. He also obtained the title as Certified Public Accountant in 2012. He has been a faculty member in the department of Accounting and Auditing at Istanbul Commerce University since 2004. His research interests include independent audit, international auditing standards, accounting profession ethical standards.

Mohamed Issa, Graduated from University of Benghazi, Faculty of Economics, department of Accounting in spring 2005. Then, he completed his

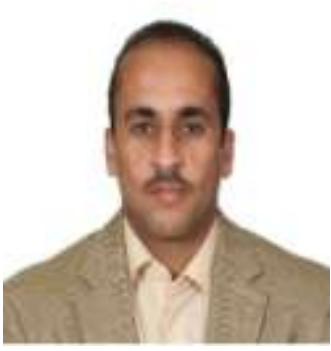
Master's Degree in Accounting from Middle Tennessee State University, Business School, department of Accounting, spring 2011. He completed his $\mathrm{Ph} . \mathrm{D}$ in Business Administration (Specialized in Accounting) from Okan University in 2017. He is a faculty member in the department of Accounting at University of Benghazi. He has an interest in the field of forensic accounting, auditing and accounting education.

Citation: Ali Altuğ Biçer \& Mohamed Issa. " Perception of Forensic Accounting Education as a Tool for Anti-Fraud in Libya " International Journal of Managerial Studies and Research (IJMSR), vol 5, no. 11, 2017, pp. 83-89. doi: http://dx.doi.org/10.20431/2349-0349.0511009.

Copyright: ( $) 2017$ Authors. This is an open-access article distributed under the terms of the Creative Commons Attribution License, which permits unrestricted use, distribution, and reproduction in any medium, provided the original author and source are credited. 